\title{
Single-centre experience of allogeneic haemopoietic stem cell transplant in paediatric patients in Cape Town, South Africa
}

\author{
A van Eyssen, ${ }^{1} \mathrm{MB} \mathrm{ChB}, \mathrm{DCH}(\mathrm{SA}), \mathrm{FC}$ Paed (SA), Cert Medical Oncology Paediatrics (SA); N Novitsky, ${ }^{2} \mathrm{FCP}(\mathrm{SA}), \mathrm{PhD}$; \\ P de Witt, ${ }^{2}$ MB ChB, FCP (SA), MMedSc (Critical Care), Cert Clinical Haematology (SA) Phys; T Schlaphoff, ${ }^{3}$ MDipTech (Med Tech); \\ V Thomas, ${ }^{2}$ ND Med Tech; D Pillay, ${ }^{2}$ MDipTech (Med Tech); M Hendricks, ${ }^{1}$ MB ChB, Dip PEC (SA), DCH (SA), FC Paed (SA), Cert \\ Medical Oncology Paediatrics (SA); A Davidson, ${ }^{1} \mathrm{MB}$ ChB, DCH (SA), FC Paed (SA), Cert Medical Oncology Paediatrics (SA), MPhil
}

\author{
${ }^{1}$ Haematology Oncology Service, Department of Paediatrics and Child Health, Red Cross War Memorial Children's Hospital and Faculty of \\ Health Sciences, University of Cape Town, South Africa \\ ${ }^{2}$ Division of Haematology/Bone Marrow Transplantation Service, Department of Medicine, Groote Schuur Hospital, University of Cape Town \\ Private Academic Hospital and Faculty of Health Sciences, University of Cape Town, South Africa \\ ${ }^{3}$ South African Bone Marrow Registry, Cape Town, South Africa
}

Corresponding author: A van Eyssen (ann.vaneyssen@uct.ac.za)

\begin{abstract}
Background. Allogeneic haemopoietic stem cell transplant (Allo-HSCT) is a specialised and costly intervention, associated with significant morbidity and mortality. It is used to treat a broad range of paediatric conditions. South Africa (SA) is an upper middle-income country with limitations on healthcare spending. The role of paediatric Allo-HSCT in this setting is reviewed.

Objectives. To review paediatric patients who underwent Allo-HSCT at the Groote Schuur Hospital/University of Cape Town Private Academic Hospital transplant unit in Cape Town, South Africa, and received post-transplant care at Red Cross War Memorial Children's Hospital, over the period January 2006 - December 2014 in respect of indications for the transplant, donor sources, conditioning regimens, treatment-related morbidity and overall survival (OS).

Methods. A retrospective analysis of patient records was performed and a database was created in Microsoft Access. Descriptive analyses of relevant demographic, clinical and laboratory data were performed. Summary statistics of demographic and clinical parameters were derived with Excel. OS was calculated from the date of transplant to the date of an event (death) or last follow-up using the Kaplan-Meier method in Statistica.

Results. A total of 48 children received Allo-HSCT: 24 for haematological malignancies, 20 for non-oncological haematological conditions, 3 for immune disorders and 1 for adrenoleukodystrophy. There were 28 boys (median age 7.5 years) and 20 girls ( 8.5 years). There were 31 sibling matched peripheral-blood stem cell (PBSC) transplants and 1 maternal haploidentical PBSC transplant. Stem cells were mobilised from bone marrow into peripheral blood by administering granulocyte-colony stimulating factor to donors. PBSCs were harvested by apheresis. Eight patients received 10/10 HLA-matched grafts from unrelated donors. Six were PBSC grafts and 2 were bone marrow grafts. Three of the unrelated PBSC grafts were from SA donors. Eight transplants used umbilical cord blood from international registries. OS for patients with non-oncological disorders was $91.3 \%$ (median follow-up 3.9 years), while that for oncology patients was $56.8 \%$ (1.9 years). Two of the survivors developed chronic graft-versus-host disease.

Conclusions. OS for non-oncological conditions was excellent, while outcomes for oncological disorders were on par with those in highincome settings. Transplantation offers many patients the opportunity for long-term survival and has been shown to be both feasible and rewarding in a less well-resourced environment servicing an economically diverse population.
\end{abstract}

S Afr Med J 2017;107(3):232-238. DOI:10.7196/SAMJ.2017.v107i3.11313

Allogeneic haemopoietic stem cell transplant (Allo-HSCT) is used to treat a broad but well-defined range of paediatric conditions most frequently in paediatric oncology for treatment intensification or salvage therapy for acute myeloid leukaemia (AML) and acute lymphoblastic leukaemia (ALL). Allo-HSCT is also indicated in juvenile myelomonocytic leukaemia (JMML) should a suitable donor be available. ${ }^{[1]}$ There is still a role for sibling matched Allo-HSCT in chronic myeloid leukaemia (CML), despite the good long-term survival demonstrated with the use of tyrosine kinase inhibitors. ${ }^{[2]}$ Allo-HSCT is also used as salvage therapy in the treatment of paediatric lymphoma. ${ }^{[3]}$ In 2007, 150 new cases of leukaemia per annum in children aged $<14$ years were being captured on the South African Children's Cancer Group registry. ${ }^{[4]}$ Only a small number of these children with high-risk disease require Allo-HSCT. ${ }^{[5,6]}$ The current demography of donors on the South African Bone Marrow
Registry (SABMR) does not represent the wide ethnic diversity of patients in our country. Owing to poor representation of local genotypes on local and international registries, a proportion of patients who qualify for treatment with Allo-HSCT cannot access a transplant because no suitable donors are available. ${ }^{[7]}$

Allo-HSCT is an effective strategy for a number of non-oncological haematological conditions such as bone marrow failure syndromes These include severe acquired aplastic anaemia (SIAA) and Fanconi's anaemia (FA) ${ }^{[8]}$ Haemoglobinopathies such as homozygous betathalassaemia and sickle cell disease (SCD) are cured with successful Allo-HSCT. ${ }^{[9]}$ At Red Cross War Memorial Children's Hospital (RCWMCH) in Cape Town, South Africa, approximately four new patients are diagnosed annually with bone marrow failure syndromes. The number of patients with SCD who attend the haematology clinic has expanded to nearly 150 . Currently 8 transfusion-dependent 
thalassaemia patients attend RCWMCH: 5 with homozygous betathalassaemia and 3 with severe haemoglobin E/beta-thalassaemia.

Primary immunodeficiency disorders (PIDs) can be ameliorated by Allo-HSCT. ${ }^{[10]}$ A recent publication ${ }^{[11]}$ highlighting new diagnostic and treatment modalities aimed to increase awareness, detection and diagnosis of PIDs among SA paediatricians. Allo-HSCT can also be used to treat rarer metabolic conditions such as the liposomal storage diseases and infantile osteopetrosis as well as adrenoleukodystrophy, in which it has been shown to arrest or slow neurodegeneration. ${ }^{[12]}$

Allo-HSCT is a highly specialised and costly intervention, associated with significant morbidity and mortality As scientific knowledge improves, so does HLA typing and matching ${ }^{[13]}$ Combined with better supportive care, this has led to improved survival rates of Allo-HSCT patients. ${ }^{[14]}$

The role of Allo-HSCT in the context of a resource-limited upper middle-income country ${ }^{[15]}$ must be reviewed and critically analysed to ensure that this intervention is being used safely and cost-effectively.

Children receiving healthcare in SA fall into two categories. According to the SA National Fiscal Review in 2011,,$^{[16]}$ the vast majority (84\%) receive state-funded healthcare. A smaller group have medical insurance. The policy at RCWMCH allows for state-funded patients to be eligible for a sibling matched transplant or a 10/10 HLAmatched transplant from an unrelated SA donor. The tissue typing and donor recruitment are funded by a non-profit organisation, the Sunflower Fund. For patients with medical insurance, an international donor search can be accessed. In recent figures quoted by the SABMR, this expense may range from ZAR300 000 to ZAR700 000, depending on where the graft is sourced and the exchange rate. Not all medical insurance policies will cover this expense.

\section{Objectives}

Paediatric patients who underwent Allo-HSCT at the Groote Schuur Hospital (GSH)/University of Cape Town (UCT) Private Academic Hospital Transplant Unit in Cape Town and received post-transplant care at RCWMCH from January 2006 to December 2014 were reviewed in respect of the indications for the transplant, donor sources, conditioning regimens, treatment-related morbidity and overall survival (OS). The results of these findings were used to assess the feasibility of Allo-HSCT as well as justify the huge demand on resources required to sustain an Allo-HSCT programme providing potential cure to a small group of patients with otherwise lifethreatening illnesses in the SA setting.

\section{Methods}

The folders of all paediatric patients, including those diagnosed and referred from other centres, who received treatment with Allo-HSCT or a bone marrow transplant at the GSH/UCT Private Academic Hospital Transplant Unit and post-transplant care at RCWMCH from January 2006 to December 2014 were retrospectively reviewed in December 2015. Follow-up was limited to the end of November 2015. A database was created in Microsoft Access 2007 (USA), and descriptive analyses of relevant demographic, clinical and laboratory data were performed. Specific data collected included sex of the patient, age at transplant, indication for transplant, treatment prior to transplant, conditioning regimens, haemopoietic stem cell (HSC) source, immunosuppression and graft-versus-host disease (GvHD) prophylaxis, documented infections (i.e. clinically significant positive blood culture, urine culture, nasopharyngeal aspirate and pus swab results), GvHD site, date of discharge from the transplant unit, cytomegalovirus (CMV) reactivation, transplant outcome and cause of death. The families of patients who were alive and did not have entries within the month of November 2015 in their folders were contacted telephonically to ascertain the child's health status.

Summary statistics of demographic, clinical and relevant laboratory parameters were derived with Excel 2007 (Microsoft, USA). OS was calculated from the date of transplant to the date of an event (death) or the last follow-up using the Kaplan-Meier method on Statistica 13.2 (StatSoft, USA).

Ethical approval was obtained from the UCT Human Research Ethics Committee (ref. no. 082/2015) and Netcare Operations Committee (ref. no. MED-2015-001).

During the transplant, infection prophylaxis included oral valacyclovir $(20 \mathrm{mg} / \mathrm{kg} /$ dose 8 -hourly) for CMV and oral co-trimoxazole $(20 / 100 \mathrm{mg}$ for patients aged $<6$ months, $40 / 200 \mathrm{mg}$ for those aged 6 months -6 years and $80 / 400 \mathrm{mg}$ for those aged $>6$ years) for Pneumocystis jiroveci pneumonia (PJP). There is evidence to support the use of valacyclovir over acyclovir in the prevention of CMV reactivation. ${ }^{[17]}$ Patients also received fluconazole ( $5 \mathrm{mg} / \mathrm{kg} / \mathrm{d}$ orally or intravenously) as fungal prophylaxis, as well as prophylactic oral ofloxacin ( $5 \mathrm{mg} / \mathrm{kg}$ 12-hourly). Primary care was provided by the transplant physicians at GSH with support from paediatric services at RCWMCH. Children remained in the unit until they achieved neutrophil engraftment, at which time they were either discharged home or transferred to RCWMCH. At GSH patients were treated in reverse isolation. Each room has laminar flow and high-efficiency particulate arrestance (HEPA) filtration, and a separate shower and toilet. Five patients were transferred to $\mathrm{RCWMCH}$ prior to engraftment because they required paediatric intensive care unit (PICU) support. During this period there were no isolation facilities or rooms with laminar flow or HEPA filtration in the RCWMCH PICU. There was a single isolation cubicle with laminar flow but no HEPA filtration in the oncology unit for bone marrow transplant patients.

Patients continued to receive supportive care at $\mathrm{RCWMCH}$ until at least 12 weeks after the transplant, with weekly $10 \mathrm{~mL} /$ $\mathrm{kg}$ infusions of stabilised human serum (SHS), surveillance for GvHD, monitoring of cyclosporine levels and CMV reactivation surveillance with polymerase chain reaction and routine blood tests including full blood count, liver function tests, measurement of electrolyte levels and tests for renal function. It is common practice to use intravenous immunoglobulin G (IVIG) for CMV prophylaxis after Allo-HSCT to decrease infections and CMV reactivation. ${ }^{[18]}$ SHS supplied by the Western Province Blood Transfusion Service is rich in immunoglobulin G $(10 \mathrm{~g} / \mathrm{L}) .{ }^{[19]}$ Although CMV prophylaxis is not one of the indications for its use, SHS was used in these patients for this purpose instead of IVIG as it was more cost-effective. Ongoing blood product support was also administered, if required, at ongoing follow-up visits at RCWMCH once patients had been discharged from hospital. Children who developed CMV reactivation were admitted to RCWMCH for administration of intravenous ganciclovir. Similarly, those who developed intercurrent infections were admitted for broadspectrum intravenous antibiotics. Patients who developed GvHD were admitted for further investigation such as colonoscopy and biopsy or skin biopsy, and management with corticosteroids and other immunosupression. CMV and PJP prophylaxis was continued until immunosuppression had been successfully withdrawn.

Once immunosupression was withdrawn, patients either remained at RCWMCH or returned to their referring centres, where follow-up continued. They were commenced on a reimmunisation schedule 1 year after the transplant. 


\section{Results}

During the 9-year study period, 48 children received an Allo-HSCT. Eighteen (37.5\%) were state-funded transplants. Twenty-eight boys (median age 7.5 years) and 20 girls (median age 8.5 years), with an overall age range of 9 months - 12.3 years, had transplants. Of the 48 patients, 38 (79.2\%) received peripheral-blood stem cell (PBSC) transplants: 31 of the PBSC grafts were 10/10 HLA-matched grafts from a sibling, 6 were HLA-matched grafts from an unrelated donor, and 1 was a maternal haploidentical graft.

Stem cells were mobilised using twice-daily subcutaneous injections of granulocyte-colony stimulating factor $5 \mu \mathrm{g} / \mathrm{kg}$ 12-hourly and harvested by apheresis on day 5 through a femoral dialysis line. Twenty of these PBSC transplants were T-cell depleted using ex vivo addition of alemtuzumab $\left(1 \mathrm{mg} / 10^{8}\right.$ mononuclear cells $)$ to the graft. ${ }^{[20]}$

Two patients received bone marrow grafts from unrelated donors. All unrelated bone marrow grafts were 10/10 HLA-matched donorrecipient pairs. Eight patients received umbilical cord blood (UCB) transplants from international registries. Three of the unrelated HLAmatched grafts were from SA donors. Procurement of all unrelated grafts was facilitated by the SABMR.

There were 24 patients who received an Allo-HSCT for an underlying malignancy. These transplants are described in Table 1.

Of the 10 patients who received transplants for ALL, 9 had relapsed disease and were in a second or subsequent remission. One patient was transplanted in first remission for a balanced translocation $(1 ; 19)$. Five of the ALL patients died after the transplant. One patient died of relapsed disease, 7 months after a nonT-cell-depleted PBSC transplant, 1 died of pneumonia 1 month after a 4/6 HLA-matched unrelated UCB transplant, and 3 died of complications of GvHD after the transplant. These patients were a child who died 2 months after a 6/6 HLA-matched unrelated UCB transplant following a complicated course including BK virus infection, cyclosporine toxicity, renal failure, central pontine myelinolysis and adenovirus pneumonia, a child who died 4 months after a 4/6 HLA-matched unrelated UCB transplant following an ascending BK virus infection involving the kidney, and a child who died from chronic lung disease 5 months after a non-T-cell-depleted sibling matched PBSC transplant.

Nine patients with AML received transplants. Only 2 of these had relapsed disease. They were both in remission following reinduction chemotherapy before the transplant, and both died after the transplant. One patient relapsed, while the other developed chronic GvHD and died from sepsis. The other 7 AML patients were transplanted in first remission because of assignment of high risk based on cytogenetics, or poor response to induction chemotherapy. Four children were referred for transplantation because they were not in remission at the end of the induction. Two of these children died from relapsed disease after the transplant. At RCWMCH all patients with AML, except those with good-risk cytogenetics, are considered for sibling HLA-matched Allo-HSCT in first remission. There was one such patient in this cohort of nine. Good-risk cytogenetics include translocation $(8 ; 21)$, inversion 16 and translocation $(16 ; 16)$. Standard-risk patients include all those with neither good- nor poor-risk cytogenetics and those who are in remission after the first induction block. There was one patient who met these criteria. Poorrisk cytogenetics include monosomy 5 or 7 , deletion ( $5 q$ ), abnormal $(3 q)$, translocation $(9 ; 22)$ and more than five major karyotype abnormalities. Two patients with monosomy 7 were transplanted.

The two patients transplanted for JMML were both alive and well at the time of writing, the patient who received a 5/6 HLA-matched unrelated UCB transplant at 6 years after the transplant and the patient who received the matched unrelated PBSC transplant at 4 years and 7 months after the transplant.

There were 24 patients who received transplants for nononcological indications (Table 2), of whom 14 were alive and in remission at the time of writing, with a median follow-up of 1.86 years (range 36 days - 7.3 years). OS was $56.8 \%$. Transplantrelated mortality (TRM) at 100 days post transplant was $12.5 \%$. Fig. 1 demonstrates the overall survival curve for these transplants.

Six children had transfusion-dependent disorders: 4 had thalassaemia major, 1 sideroblastic anaemia (SA) and 1 haemolytic anaemia (HA). HA is an unusual indication for Allo-HSCT, and the decision to recommend Allo-HSCT in this patient was made after exhaustive testing failed to identify the cause of the child's ongoing haemolysis, which required ongoing regular transfusion. Two patients had SCD, one of whom had sickle-haemoglobin D-Punjab. Both patients had recurrent painful crises, and matched sibling donors were available. They received non-T-cell-depleted PBSC grafts.

Eleven patients had bone marrow failure syndromes. Of these, 4 had SIAA: 3 of these patients received T-cell-depleted sibling matched PBSC grafts and 1 a 10/10 HLA-matched unrelated PBSC graft from an international donor. Seven patients had FA. Of these, 5 received sibling matched PBSC grafts, 3 of which were T-cell depleted, 1 received a T-cell-depleted sibling matched bone marrow graft, and 1 received a T-cell-depleted matched unrelated PBSC graft. One patient with myelodysplasia (MD) received a non-T-cell-depleted matched unrelated PBSC graft. There was only 1 death among these 11 patients. This was a patient with FA transplanted with a non-T-cell-depleted sibling matched PBSC graft who developed GvHD and then died of graft failure 5 months after the transplant.

Three children were transplanted for immunodeficiency. These included 2 patients with severe combined immunodeficiency disorder (SCID), of whom 1 received a 5/6 HLA-matched UCB graft and 1 a T-cell-depleted maternal haploidentical PBSC graft. The third patient had immunodysregulation polyendocrinopathy enteropathy X-linked (IPEX) syndrome. This patient received a 10/10 HLAmatched unrelated graft. All 3 patients were alive at the time of writing.

One child with adrenoleukodystrophy received a non-T-celldepleted sibling matched PBSC graft. He was doing well at the time of writing, and his neuroregression had been arrested.

Of the 24 patients transplanted for non-oncological conditions, 22 were alive at the time of writing, at a median follow-up of 3.94 years (range 87 days -9.22 years). OS was $91.3 \%$, and TRM at 100 days post transplant was $0 \%$. The overall survival curve for these transplants is shown in Fig. 2.

Three patients have experienced chronic GvHD. Two of these patients were still receiving immunosuppression at the time of writing. Both had received T-cell-depleted sibling matched PBSC transplants, the first patient for relapsed ALL and the other for SIAA. The patient with ALL was receiving low-dose prednisone for chronic immune-mediated fasciitis 17 months post transplant. The patient with SIAA, who was being treated with mycophenolic acid and prednisone for eosinophilic myositis and fasciitis, was 4 years and 8 months post transplant at the time of writing. The third patient, who was transplanted for SCD, had chronic GvHD involving the skin, gut and liver and eosinophilic myositis and fasciitis with a complex regional pain syndrome requiring long-term treatment with corticosteroids and tacrolimus for 2 years post transplant. This patient was doing well after 1 year off all immunosuppression. 
Table 1. Transplants for oncological indications

\begin{tabular}{|c|c|c|c|c|c|c|c|c|}
\hline $\begin{array}{l}\text { Case } \\
\text { no. }\end{array}$ & Graft & $\begin{array}{l}\text { T-cell } \\
\text { depleted }\end{array}$ & Diagnosis & $\begin{array}{l}\text { Indication for } \\
\text { transplant }\end{array}$ & Conditioning regimens & $\begin{array}{l}\text { GvHD } \\
\text { prophylaxis }\end{array}$ & $\begin{array}{l}\text { CMV } \\
\text { reactivation }\end{array}$ & Outcome \\
\hline 1 & UCB $6 / 6$ & No & ALL & Relapsed disease & TBI/fludarabine & Cyclosporine & No & $\begin{array}{l}\text { Died } 4 \text { mo post transplant } \\
\text { from acute GvHD/adeno- } \\
\text { virus/renal failure }\end{array}$ \\
\hline 2 & UCB 5/6 & No & JMML & $\begin{array}{l}\text { Failed ATRA } \\
\text { treatment }\end{array}$ & $\begin{array}{l}\text { Busulphan/fludarabine/ } \\
\text { melphalan }\end{array}$ & Cyclosporine & No & Alive and well \\
\hline 3 & UCB 5/6 & No & $\begin{array}{l}\text { Hepatosplenic } \\
\text { gamma/delta } \\
\text { lymphoma }\end{array}$ & $\begin{array}{l}\text { Hepatosplenic } \\
\text { gamma/delta } \\
\text { lymphoma }\end{array}$ & $\begin{array}{l}\text { Busulphan/fludarabine/ } \\
\text { melphalan }\end{array}$ & Cyclosporine & No & Alive and well \\
\hline 4 & UCB $5 / 6$ & Yes & ALL & Relapsed disease & TBI/fludarabine & Cyclosporine & No & Alive and well \\
\hline 5 & UCB $4 / 6$ & No & ALL & Relapsed disease & $\begin{array}{l}\text { TBI/fludarabine/ } \\
\text { cyclophosphamide/ATG }\end{array}$ & Cyclosporine & No & $\begin{array}{l}\text { Died } 1 \text { mo post transplant } \\
\text { from pneumonia }\end{array}$ \\
\hline 6 & UCB $4 / 6$ & No & ALL & Relapsed disease & $\begin{array}{l}\text { TBI/fludarabine/ } \\
\text { cyclophosphamide/ATG }\end{array}$ & Cyclosporine & No & $\begin{array}{l}\text { Died } 4 \text { mo post transplant } \\
\text { from acute GvHD }\end{array}$ \\
\hline 7 & UCB $4 / 6$ & No & AML & $\begin{array}{l}\text { AML monosomy } \\
7\end{array}$ & $\begin{array}{l}\text { Busulphan/melphalan/ } \\
\text { cyclophosphamide }\end{array}$ & Cyclosporine & No & $\begin{array}{l}\text { Died } 3.5 \text { mo post } \\
\text { transplant from acute gut } \\
\text { GvHD }\end{array}$ \\
\hline 8 & $\begin{array}{l}\text { Sibling matched } \\
\text { PBSC }\end{array}$ & No & ALL & Relapsed disease & $\begin{array}{l}\text { TBI/fludarabine/ } \\
\text { cyclophosphamide/ATG }\end{array}$ & Cyclosporine & No & $\begin{array}{l}\text { Died } 7 \text { mo post transplant } \\
\text { from relapsed ALL }\end{array}$ \\
\hline 9 & $\begin{array}{l}\text { Sibling matched } \\
\text { PBSC }\end{array}$ & No & ALL & Relapsed disease & $\begin{array}{l}\text { TBI/fludarabine/ } \\
\text { cyclophosphamide }\end{array}$ & Cyclosporine & No & $\begin{array}{l}\text { Died } 5 \text { mo post transplant } \\
\text { from chronic lung GvHD }\end{array}$ \\
\hline 10 & $\begin{array}{l}\text { Sibling matched } \\
\text { PBSC }\end{array}$ & No & ALL & Relapsed disease & $\begin{array}{l}\text { TBI/fludarabine/ } \\
\text { cyclophosphamide }\end{array}$ & $\begin{array}{l}\text { Cyclosporine/ } \\
\text { methotrexate }\end{array}$ & No & Alive and well \\
\hline 11 & $\begin{array}{l}\text { Sibling matched } \\
\text { PBSC }\end{array}$ & No & ALL & Relapsed disease & $\begin{array}{l}\text { TBI/fludarabine/ } \\
\text { cyclophosphamide }\end{array}$ & Cyclosporine & No & Alive and well \\
\hline 12 & $\begin{array}{l}\text { Sibling matched } \\
\text { PBSC }\end{array}$ & Yes & ALL & Relapsed disease & TBI/fludarabine & Cyclosporine & No & $\begin{array}{l}\text { Alive } \\
\text { Chronic GvHD }\end{array}$ \\
\hline 13 & $\begin{array}{l}\text { Sibling matched } \\
\text { PBSC }\end{array}$ & Yes & ALL & $\begin{array}{l}\text { Translocation } \\
(1 ; 19)\end{array}$ & TBI/fludarabine & Cyclosporine & Yes & Alive and well \\
\hline 14 & $\begin{array}{l}\text { Sibling matched } \\
\text { PBSC }\end{array}$ & Yes & AML & $\begin{array}{l}\text { Failure to remit } \\
\text { after induction } 1\end{array}$ & $\begin{array}{l}\text { Busulphan/melphalan/ } \\
\text { cyclophosphamide }\end{array}$ & Cyclosporine & Yes & Alive and well \\
\hline 15 & $\begin{array}{l}\text { Sibling matched } \\
\text { PBSC }\end{array}$ & Yes & AML & Relapsed disease & $\begin{array}{l}\text { Busulphan/melphalan/ } \\
\text { cyclophosphamide }\end{array}$ & Cyclosporine & No & $\begin{array}{l}\text { Died } 26 \text { mo post } \\
\text { transplant of relapsed } \\
\text { disease }\end{array}$ \\
\hline 16 & $\begin{array}{l}\text { Sibling matched } \\
\text { PBSC }\end{array}$ & Yes & AML & $\begin{array}{l}\text { Failure to remit } \\
\text { after induction } 1\end{array}$ & $\begin{array}{l}\text { Reduced intensity: } \\
\text { busulphan/melphalan/ } \\
\text { fludarabine }\end{array}$ & Cyclosporine & No & $\begin{array}{l}\text { Died } 8 \text { mo post transplant } \\
\text { of relapsed disease }\end{array}$ \\
\hline 17 & $\begin{array}{l}\text { Sibling matched } \\
\text { PBSC }\end{array}$ & No & AML & $\begin{array}{l}\text { Failure to remit } \\
\text { after induction } 1\end{array}$ & $\begin{array}{l}\text { Busulphan/melphalan/ } \\
\text { cyclophosphamide }\end{array}$ & Cyclosporine & Yes & $\begin{array}{l}\text { Died } 5 \text { mo post transplant } \\
\text { of relapsed disease }\end{array}$ \\
\hline 18 & $\begin{array}{l}\text { Sibling matched } \\
\text { PBSC }\end{array}$ & No & AML & Relapsed disease & $\begin{array}{l}\text { Busulphan/melphalan/ } \\
\text { cyclophosphamide }\end{array}$ & $\begin{array}{l}\text { Cyclosporine/ } \\
\text { methotrexate }\end{array}$ & Yes & $\begin{array}{l}\text { Died } 6 \text { mo post transplant } \\
\text { of chronic GvHD/sepsis }\end{array}$ \\
\hline 19 & $\begin{array}{l}\text { Sibling matched } \\
\text { PBSC }\end{array}$ & Yes & AML & $\begin{array}{l}\text { Standard risk } \\
\text { with sibling } \\
\text { donor available }\end{array}$ & $\begin{array}{l}\text { Busulphan/melphalan/ } \\
\text { cyclophosphamide/ATG }\end{array}$ & Cyclosporine & No & Alive and well \\
\hline 20 & $\begin{array}{l}\text { Sibling matched } \\
\text { PBSC }\end{array}$ & Yes & AML & $\begin{array}{l}\text { Failure to remit } \\
\text { after induction } 1\end{array}$ & $\begin{array}{l}\text { Busulphan/melphalan/ } \\
\text { cyclophosphamide }\end{array}$ & Cyclosporine & Yes & Alive and well \\
\hline 21 & $\begin{array}{l}\text { Sibling matched } \\
\text { PBSC }\end{array}$ & No & CML & $\begin{array}{l}\text { Relapsed on } \\
\text { imatinib }\end{array}$ & $\begin{array}{l}\text { Busulphan/melphalan/ } \\
\text { cyclophosphamide }\end{array}$ & Cyclosporine & No & Alive and well \\
\hline 22 & $\begin{array}{l}\text { Matched } \\
\text { unrelated PBSC }\end{array}$ & Yes & AML & $\begin{array}{l}\text { AML monosomy } \\
7\end{array}$ & $\begin{array}{l}\text { Busulphan/melphalan/ } \\
\text { cyclophosphamide/ATG }\end{array}$ & Cyclosporine & Yes & Alive and well \\
\hline 23 & $\begin{array}{l}\text { Matched } \\
\text { unrelated PBSC }\end{array}$ & No & JMML & $\begin{array}{l}\text { Failed CRA } \\
\text { treatment }\end{array}$ & $\begin{array}{l}\text { Busulphan/melphalan/ } \\
\text { cyclophosphamide/ATG }\end{array}$ & Cyclosporine & No & Alive and well \\
\hline 24 & $\begin{array}{l}\text { Matched } \\
\text { unrelated PBSC }\end{array}$ & Yes & ALCL & Relapsed disease & $\begin{array}{l}\text { Busulphan/melphalan/ } \\
\text { cyclophosphamide/ATG }\end{array}$ & Cyclosporine & No & Alive and well \\
\hline
\end{tabular}


Table 2. Transplants for non-oncological indications

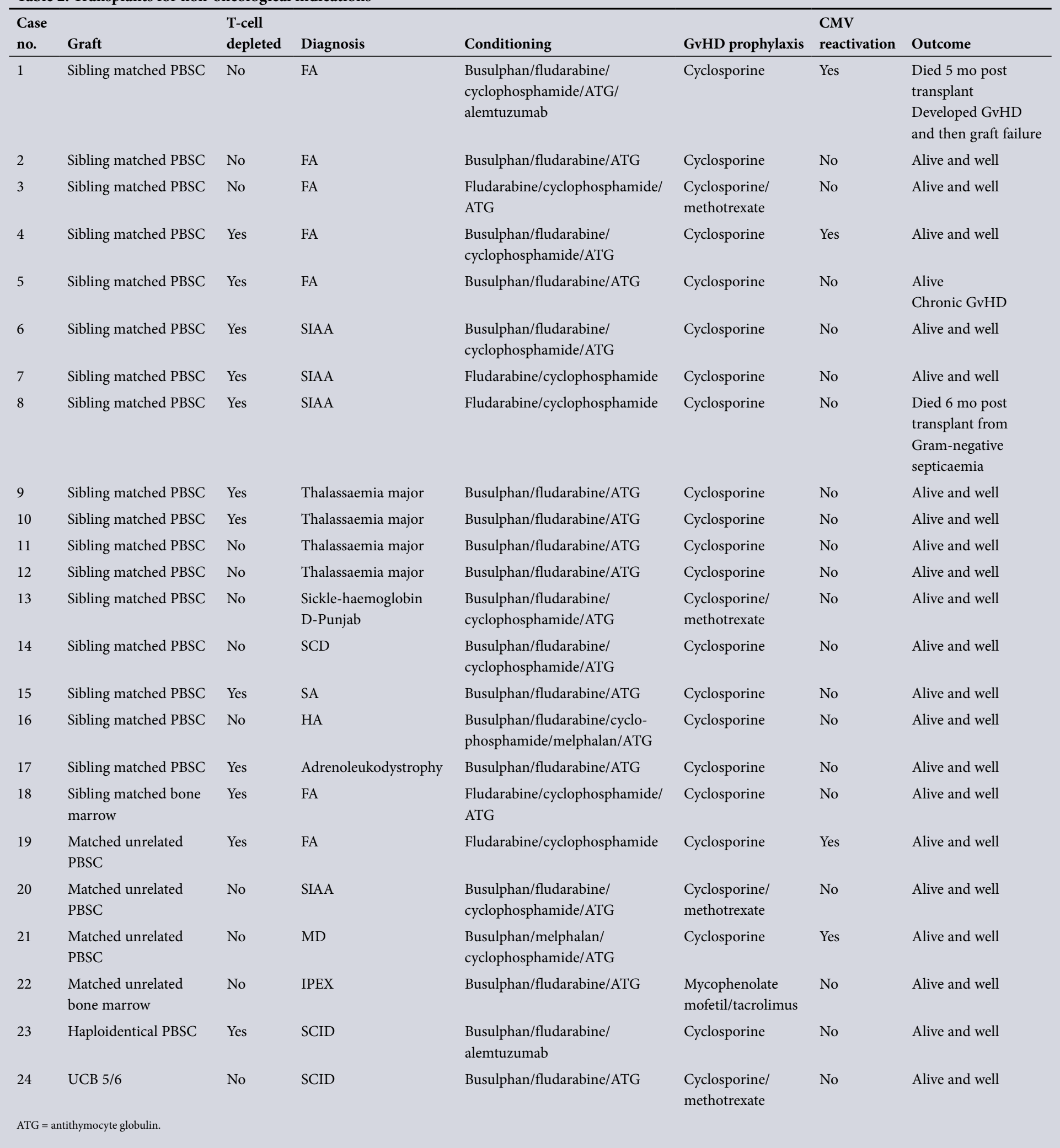

\section{Discussion}

The Cape Town paediatric transplant experience has been a major success, demonstrating OS of $91.3 \%$ with median follow-up of 3.94 years for non-oncological indications. TRM at 100 days post transplant for non-oncological indications was $0 \%$. The OS for haematopoietic malignancies was $56.8 \%$ with a median follow-up of 1.86 years and TRM at 100 days post transplant of $12.5 \%$. It is not possible to compare the outcomes of Allo-HSCT performed for oncological and non-oncological conditions. Our outcomes (OS 44.4\%) for children treated for relapsed ALL are in keeping with experience in the developed world, ${ }^{[5,21]}$ and Allo-HSCT offered the best potential cure to these children. The results for patients with 


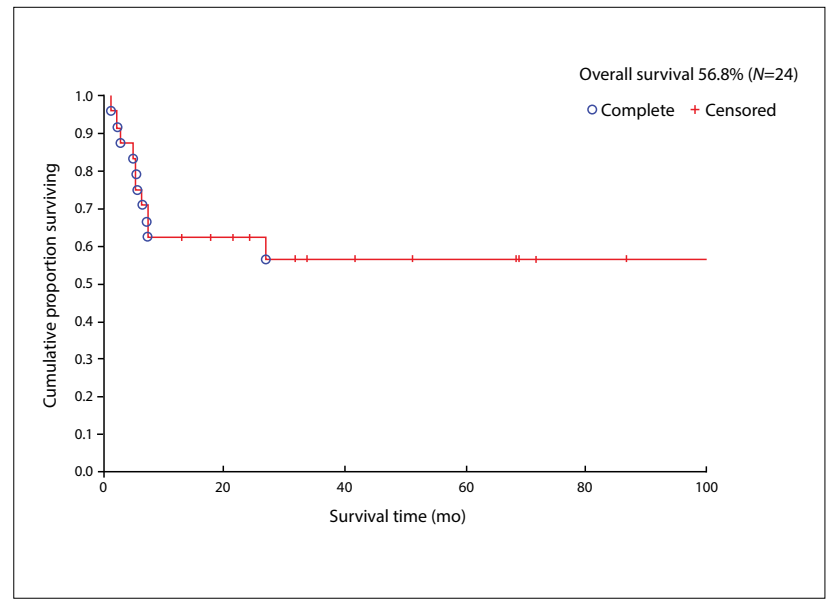

Fig. 1. Overall survival curve for oncological indications.

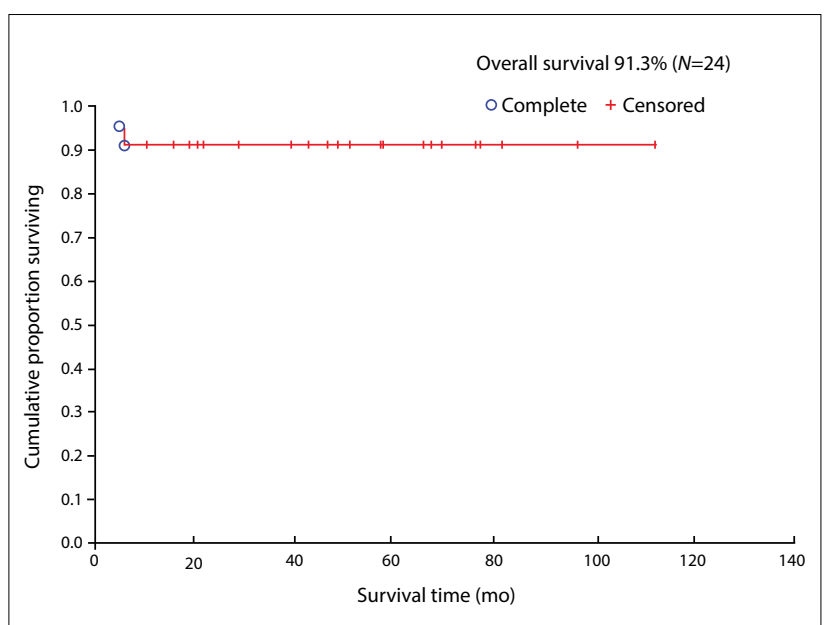

Fig. 2. Overall survival curve for non-oncological indications.

AML (OS 44.4\%) are also comparable to those from units in highincome settings. ${ }^{[22]}$

Only three of the 36 surviving patients (8.3\%) have experienced chronic GvHD requiring ongoing immunosuppression, suggesting that ex vivo T-cell depletion of the PBSC grafts has been effective in reducing the incidence of GvHD. Some of the literature on paediatric Allo-HSCT favours the use of bone marrow as a source of graft over PBSCs owing to the increased risk of chronic GvHD with PBSCs. ${ }^{[23]}$ Most of the transplants at GSH and the UCT Private Academic Hospital made use of PBSC grafts. The use of T-cell depletion by exposure of the PBSC graft to alemtuzumab ex vivo to prevent GvHD was described by Hale and Waldmann ${ }^{[24]}$ in 1993 . Wood et al. ${ }^{[25]}$ from Cape Town reported gratifying results with regard to quality of life and a low incidence of GvHD when using this technique in an adult population in 1994. Our experience has corroborated these findings.

Although T-cell depletion may carry the potential risk of increased viral complications after the transplant, ${ }^{[26]}$ we have found ex vivo immunodepletion of grafts to be effective and safe, with only 9 of 48 transplants (18.8\%) being complicated by CMV reactivation. There were no deaths due to CMV reactivation, but one patient was re-transplanted after overwhelming CMV infection resulted in graft failure. The patient did very well after the second graft. This is in keeping with the morbidity described in an adult cohort from GSH ${ }^{[27]}$ and is also below the $30 \%$ suggested by Azevedo et al. ${ }^{[28]}$

Successful Allo-HSCT can significantly improve quality of life for patients requiring regular transfusion. ${ }^{[9]}$ It reduces the cumulative financial burden of blood products, chelation and treatment of iron overload-related morbidity, which place an enormous load on an already overburdened healthcare system. Current monthly cost estimates for a child include admission to hospital (ZAR1 900/day), filtered packed red cells (ZAR1 500/unit) and chelation (deferasirox ZAR2 300 - 5 000/month). Our considerable success in this group of patients, although a small cohort $(n=4)$, suggests that Allo-HSCT is a very favourable therapeutic intervention in these cases.

Allo-HSCT is the only curative option for children affected by SCD, offering longevity and improved quality of life if performed timeously and for the correct indications. Current guidelines for paediatric patients are that it should be reserved for children aged $<17$ years, those with severe symptoms of SCD, unresponsive to hydroxyurea, and those with SCD-related organ damage (e.g. stroke, acute chest syndrome, multiple sites of osteonecrosis), if a sibling matched donor is available. ${ }^{[9]}$ As migration brings a growing number of these patients into $S A,{ }^{[29]}$ transplantation may need to be considered to an increasing extent.

\section{Conclusions}

In this cohort, the source of HSCs and access to Allo-HSCT were largely determined by the patients' economic resources and availability of suitable donors on the SABMR. OS for non-oncological conditions was excellent, while outcomes for oncological disorders were on par with those in high-income settings. Transplantation presented the best opportunity for long-term survival for the children who underwent the procedure.

Allo-HSCT has an important role to play in the management of paediatric patients. Despite local resource challenges, innovative and judicious use of this modality in respect of indication and recipient choice, as well as HSC source, will ensure successful outcomes and sustainability of this instrument. Patients who are eligible for AlloHSCT and their siblings should therefore be tissue typed. Increasing donor awareness is critical in SA. Higher numbers of available local donors increase patients' chance of a suitable HLA match.

1. Miano M, Labopin M, Hartmann O, Angelucci E, et al. Haematopoietic stem cell transplantation trends in children over the last three decades: A survey by the Paediatric Diseases Working Party at the European Group for Blood and Marrow Transplantation. Bone Marrow Transplant 2007;39(2):89-99. http://dx.doi.org/10.1038/sj.bmt.1705550

2. Andolina J, Neudorf S, Corey S. How I treat childhood CML. Blood 2012;119(8):1821-1830. http:// dx.doi.org/10.1182/blood-2011-10-380774

. Attarbaschi A, Dworzak M, Steiner M, Urban C. Outcome of children with primary resistant or relapsed non-Hodgkin lymphoma and mature B cell leukaemia after intensive first-line treatment: A population-based analysis of the Austrian Cooperative Study Group. Pediatr Blood Cancer 2005;44(1):70-76. http://dx.doi.org/10.1002/pbc.20121

4. Stefan DC. Epidemiology of childhood cancer and the SACCSG tumour registry. CME 2010;28(7):317319.

5. Einsiedel HG, von Stackelberg A, Hartmann R, et al. Long-term outcome in children with relapsed Einsiedel HG, von Stackelberg A, Hartmann R, et al. Long-term outcome in children with relapsed
ALL by risk-stratified salvage therapy: Results of Trial Acute Lymphoblastic Leukaemia-Relapse ALL by risk-stratified salvage therapy: Results of Trial Acute Lymphoblastic Leukaemia-Relapse
Study of the Berlin-Frankfurt-Munster Group 87. J Clin Oncol 2005;23(31):7942-7950. http://dx.doi. Study of the Berlin-Frankfurt-
org/10.1200/JCO.2005.01.1031

6. Niewerth D, Creutzig U, Bierings M, Kaspers G. A review on allogeneic stem cell transplantation for newly diagnosed pediatric acute myeloid leukaemia. Blood 2010;116(13):2205-2214. http://dx.doi. org/10.1182/blood-2010-01-261800

7. Du Toit E, Schlaphoff T, Borril V. The South African bone marrow registry role in providing unrelated donors for allogeneic stem cell transplantation. CME 2012;30(8):293-294.

8. Myers KC, Davies SM. Hematopoietic stem cell transplantation for bone marrow failure syndromes in children. Biol Blood Marrow Transplant 2009;15(3):279-292. http://dx.doi.org/10.1016/j.bbmt.2008.11.037 9. Angelucci E, Matthes-Martin S, Baronciani D, et al. Hematopoietic stem cell transplantation in thalassaemia major and sickle cell disease: Indications and management recommendations from an expert international expert panel. Haematologica 2014;99(5):811-820. http://dx.doi.org/10.3324/ haematol.2013.099747

10. Mitchell R, Nivison-Smith I, Anazodo A, et al. Outcomes of hematopoietic stem cell transplantation in primary immunodeficiency: A report from the Australian and New Zealand Children's Haematology
inglation primary immunodeficiency: A report from the Australian and New Zealand Children's Haematology
Oncology Group and the Australasian Bone Marrow Transplant Recipient Registry. Biol Blood Oncology Group and the Australasian Bone Marrow Transplant Recipient Registry.
Marrow Transplant 2013;19(3):338-343. http://dx.doi.org/10.1016/.bbmt.2012.11.619

Marrow Transplant 2013;19(3):338-343. http://dx.doi.org/10.1016/j.bbmt.2012.11.619
1. Eley B, Esser M. Investigation and management of primary immunodeficiency in South African children. S Afr Med J 2014;104(11):793. http://dx.doi.org/10.7196/SAMJ.8946

12. Passweg JR, Baldomero H, Peters C, et al. Hematopoietic SCT in Europe: Data and trends in 2012 with special consideration of pediatric transplantation. Bone Marrow Transplant 2014;49(6):744-750. http://dx.doi.org/10.1038/bmt.2014.55

13. Harvey J, Green A, Cornish J, et al. Improved survival in matched unrelated donor transplant for ALL since the introduction of high resolution matching at HLA class I and II. Bone Marrow Transplant 2012;47(10):1294-1300. http://dx.doi.org/10.1038/bmt.2012.8 
14. Lee SJ, Astigarraga CC, M Eapen, et al. Variation in supportive care practices in hematopoietic cell transplantation. Biol Blood Marrow Transplant 2008;14(11):1231-1238. http://dx.doi.org/10.1016/j. bbmt.2008.08.008

15. World Bank. Data: South Africa, 2016. http://data.worldbank.org/country/south-africa (accessed 15 October 2016).

16. South Africa.info. Brand South Africảs information gateway to South Africa. https://www.southafrica.info/ about/health/health.htm\#.WAnNgvl96Uk (accessed 15 October 2016).

17. Ljungman P, de la Camara R, Milpied N, et al. Randomized study of valaciclovir as prophylaxis against cytomegalovirus reactivation in recipients of allogeneic bone marrow transplants. Blood 2002;99(8):30503056. https://doi.org/10.1182/blood.V99.8.3050

18. Cordonnier C, Chevret S, Legrand M, et al. Should immunoglobulin therapy be used in allogeneic stem-cell transplantation? A randomized, double-blind, dose effect, placebo-controlled, multicenter trial. Ann Intern Med 2003;139(1):8-18. http://doi.org/10.7326/0003-4819-139-1-200307010-00007

19. Norlin AC, Sairafi D, Mattsson J, Ljungman P, Ringdén O, Remberger M. Allogeneic stem cell transplantation: Low immunoglobulin levels associated with decreased survival. Bone Marrow Transplant 2008;41(3):267-273. http://dx.doi.org/10.1038/sj.bmt.1705892

20. Western Province Blood Transfusion Service. Clinical information: Products and services 2008. http://www. wpbtsmedical.org.za/sites/default/files/Fractionation-PackageInsertSHS.pdf (accessed 20 October 2016).

21. Novitzky N, Thomas V. Allogeneic stem cell transplantation with T cell-depleted grafts for lymphoproliferative malignancies. Biol Blood Marrow Transplant 2007;13(1):107-115. http://dx.doi. lymphoproliferative malignancies.
org/10.1016/.jbmt.2006.09.004

22. Tracey J, Zhang M, Thiel E, Sobocinski KA, Eapen M. Transplantation conditioning regimens and outcomes after allogeneic hematopoietic cell transplantation in children and adolescents with acute lymphoblastic leukemia. Biol Blood Marrow Transplant 2013;19(2):255-259. http://dx.doi.org/10.1016/j.bbmt.2012.09.019 23. Locatelli F, Masetti R, Rondelli R, et al. Outcome of children with high-risk acute myeloid leukemia given autologous or allogeneic hematopoietic cell transplantation in the AIEOP AML-2002/01 study. Bone Marrow Transplant 2015;50(2):181-188. http://dx.doi.org/10.1038/bmt.2014.246
24. Eapen M, Horowitz MM, Klein JP, et al. Higher mortality after allogeneic peripheral-blood transplantation compared with bone marrow in children and adolescents: The Histocompatibility and Alternate Stem compared with bone marrow in children and adolescents: The Histocompatibility and Alternate Stem
Cell Source Working Committee of the International Bone Marrow Transplant Registry. J Clin Oncol 2004:22(24):4872-4880. http://dx.doi.org/10.1200/JCO.2004.02.189

25. Hale G, Waldmann H. From laboratory to clinic: The story of CAMPATH-1. In: George AJT, Urch C, eds. Antibodies in the Clinic: Methods in Molecular Medicine. Vol 40: Diagnostic and Therapeutic Antibodies. Antibodies in the Clinic: Methods in Mole
Totowa, NJ: Humana Press, 2000:243-266.

Totowa, NJ: Humana Press, 2000:243-266.
26. Wood L, Haveman J, Juritz J, Waldmann H, Hale G, Jacobs P. Immunohematopoietic stem cell Wood L, Haveman J, Juritz J, Waldmann H, Hale G, Jacobs P. Immunohematopoietic stem cell
transplantation in Cape Town: A ten-year outcome analysis in adults. Hematol Oncol Stem Cell The transplantation in Cape Town: A ten-year outcome analysis in ad
2009;2(2):320-332. http://dx.doi.org/10.1016/1658-3876(09)50020-9

27. Hertenstein B, Hampl W, Bunjes D, et al. In vivo/ex vivo T cell depletion for GvHD prophylaxis influences onset and course of active cytomegalovirus infection and disease after BMT. Bone Marrow Transplan 1995;15(3):387-393.

28. Worldwide Network for Blood \& Marrow Transplantation. Document Archive. Cape Town 2014 Presentations. $\mathrm{T}$ cell depletion alemtuzumab in the bag. http://www.wbmt.org/fileadmin/pdf/10 CapeTown_Symp-2014/Campath_presentation_2.pdf (accessed 18 October 2016).

29. Azevedo LS, Pierotti LC, de Sousa Marques HH, et al. Cytomegalovirus infection in transplant recipients. Clinics (Sao Paulo) 2015;70(7):515-523. http://dx.doi.org/10.6061/dinics/2015(07)09

30. Wonkam A, Ponde C, Nicholson N, et al. The burden of sickle cell disease in Cape Town. S Afr Med J 2012;102(9):752-754. http://dx.doi.org/10.7196/SAMJ.5886

Accepted 22 November 2016. 